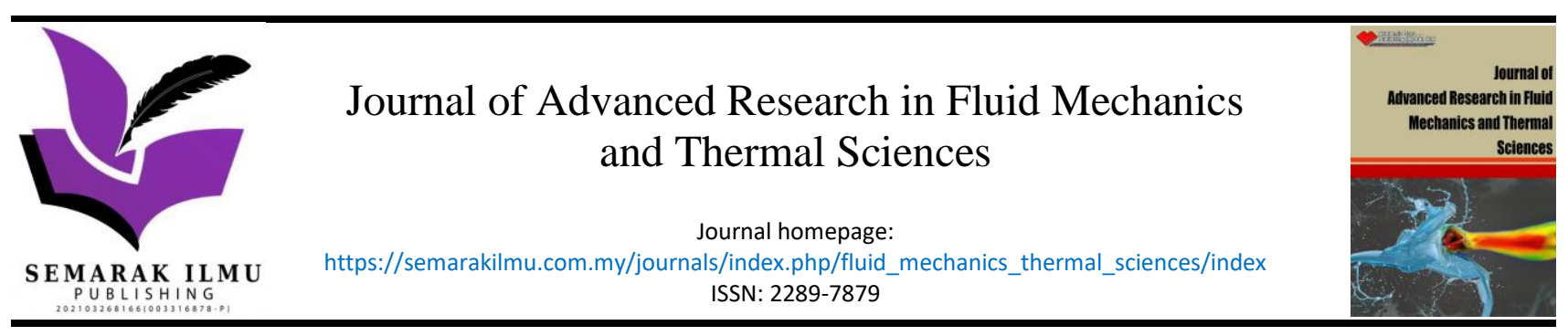

\title{
Design and Fabrication of a Domestic Biogas Unit for Cooking Applications
}

\author{
Fathima Rehana Munas ${ }^{1, *}$, J. A. D. A. S. Appuhamy², Abdul Majeed Muzathik ${ }^{1}$ \\ Department of Mechanical Engineering, South Eastern University of Sri Lanka, Sri Lanka \\ Sri Lanka Air Force Base Katunayake. Air Force Camp Rd, Katunayake, Sri Lanka
}

\section{ARTICLE INFO}

ABSTRACT

\section{Article history:}

Received 27 July 2021

Received in revised form 16 October 2021

Accepted 25 October 2021

Available online 13 November 2021
Keywords:

Biogas; Anaerobic Digestion; Organic waste; Renewable energy

\begin{abstract}
This paper presents the design and fabrication of a domestic biogas unit by using daily organic waste for cooking. Basically, this unit consists a gas storage unit and a digester barrel. Initially, the organic wastes including kitchen wastes were deposited into the digester barrel which contains water with $\mathrm{pH} 6$ once in every two days for two weeks. Then the mix started to produce biogas when the $\mathrm{pH}$ value reached around 6.8-7.5. After that food wastes were added slowly every day. When this step is continued further, the daily collection of biogases is 50 liters. As the digestate of this anaerobic digester is rich in nutrients this is also a good organic fertilizer for plants in the home garden. Also, this unit is designed and fabricated with easy maintenance and usage. Further, it is very much beneficial to dispose biodegradable kitchen wastes in an eco-friendly manner. In order to answer the energy demand in domestic level, it is highly essential to utilize the daily organic waste as a source of energy and produce methane as an alternative solution for cooking-energy requirement.
\end{abstract}

\section{Introduction}

The demand for energy is growing $6 \%$ per year in Sri Lanka and this leads to the search for alternative energy sources. Though many countries are planned to achieve carbon neutrality before 2050, Sri Lanka is forecasting to rise renewable energy capacity to reach the carbon neutrality by 2050 [1]. In this sense, Biogas is very much essential and an efficient economic way of gaining domestic renewable energy for rural communities as well as farmers [1,2]. However, the usage of bio gas is comparatively small considering with electricity from diesel generators and hydro power systems as well as petroleum products [3]. The domestic cooking in rural areas primarily uses wood as shown in Figure 1 and this leads to the serious health problems mainly for women. However, biogas is a clean fuel because it doesn't leave any dust or particulate matter during the combustion. Further, it is lighter and hence this releases less amount of carbon dioxide to the atmosphere during the burning $[1,3,4]$.

Biogas is generated from biodegradable waste which is putrid into carbon dioxide, water, methane or simple organic molecules by the action of micro-organisms within a small time [5-9].

\footnotetext{
* Corresponding author.

E-mail address: rehana@seu.ac.lk

https://doi.org/10.37934/arfmts.88.3.156164
} 
Presently, the per capita solid waste generation level in Sri Lanka varies from $0.2 \mathrm{~kg}-1.7 \mathrm{~kg}$ per day $[10,11]$. On the other hand, these biodegradable wastes are the major component of municipal solid wastes and its accumulation in landfills is challenging and causes many ecological problems [12]. However, landfilling is also leading several environmental impacts owing to the release of leachate, methane and carbon dioxide and other pests. Leachate would also pollute underground water and soil along with the release of methane $[4,12,13]$. Further, using this solid waste as a potential source for the production of sustainable fuels complete the full cycle of this waste stream sustainably and thus, directly support and facilitate the concept of the circular economy as well [12].

Though there were several biogas units developed previously these units have several drawbacks during the construction and implementation. Particularly these units have the lack of facilities to construct in household level. Further these units were not safe and cost effective for domestic applications. However, it is very much essential to introduce sustainable biogas system to the domestic market to gain cooking gas and organic fertilizer. This particular unit presented in this paper has several advantages like easy construction, safe and cost effective in domestic level. Hence, promoting this kind of small-scale biogas units would be highly valuable.
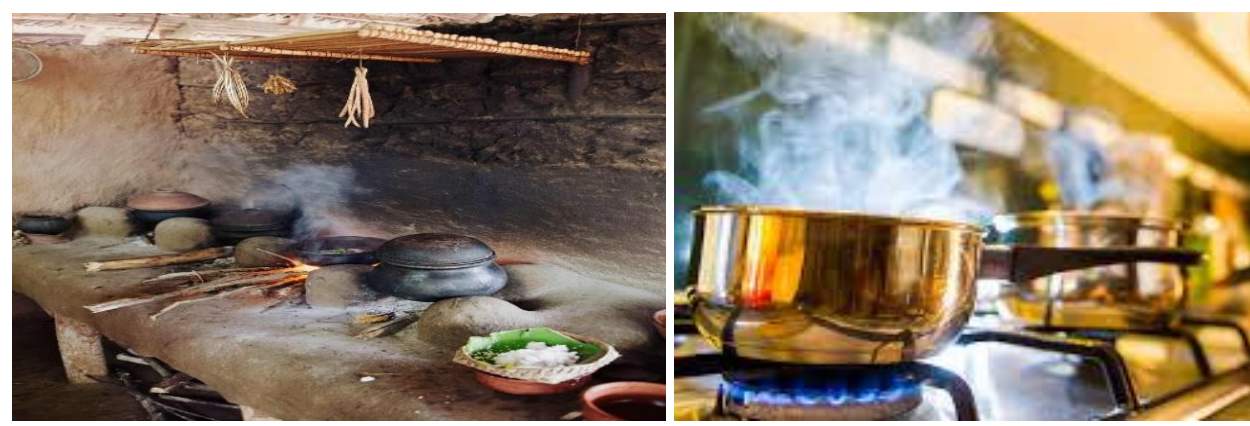

Fig. 1. Current methods of cooking in domestic sector [1]

\subsection{Process of Making Biogas and Its Composition}

Bio gas is generated through anaerobic digestion which is named as a biological process which converts biodegradable wastes into methane, carbon dioxide, hydrogen sulphide and gases in less percentage with the aid of microorganisms in the absence of oxygen [6,9,14-16]. The composition of biogas is illustrated in Table $1[6,9,14]$. During the anaerobic digestion process, initially the feed stock is collected by the anaerobic digester for the pre-treatment to increase the bio gas yield. Then this feedstock is sent to the digester. Finally, the bio gas is filled in gas storage units and the byproduct is collected separately as shown in Figure 2.

Table 1

Bio Gas Composition [14,17-19]

\begin{tabular}{ll}
\hline Compound & Vol\% \\
\hline Methane & $50-75$ \\
Carbon Dioxide & $25-50$ \\
Nitrogen & $<7$ \\
Oxygen & $<2$ \\
Hydrogen Sulfide & $<1$ \\
Ammonia & $<1$ \\
\hline
\end{tabular}




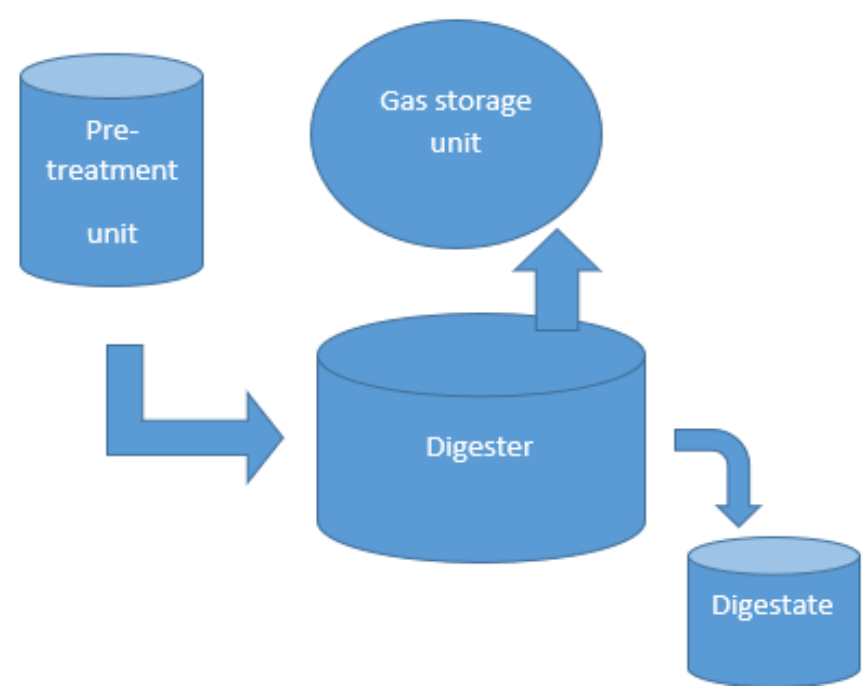

Fig. 2. Anaerobic digestion process

\subsection{Available Technologies in Biogas Production and Collection}

Though there are various technologies widely used in the production and collection of bio gas. Floating drum plant, Fixed dome plant and balloon/gas digester are some of the important techniques. Table 2 explains the prevailing bio gas production technologies $[14,17,18]$.

\section{Table 2}

Prevailing bio gas production technologies [14,17-21]

$\begin{array}{ll}\text { Type of Technology } & \text { Regional } \\ \text { deployment }\end{array}$




\begin{tabular}{|c|c|c|}
\hline Fixed- dome Model & $\begin{array}{l}\text { It consists of an inlet compartment annexed } \\
\text { with the digester which is enclosed by a dome } \\
\text { shaped unit attached with the gas outlet pipe. } \\
\text { An outlet from the digester can be fed into a } \\
\text { compost unit to get fertilizer. This model is } \\
\text { popular and this has lesser problems } \\
\text { comparing with floating drum model. But } \\
\text { Continuous flow fixed dome biogas systems } \\
\text { are widely used in Sri Lanka animal dung and } \\
\text { human excreta. In this model, there is a } \\
\text { necessity to feed the input daily if there is a } \\
\text { daily requirement [4] }\end{array}$ & $\begin{array}{l}\text { Developed } \\
\text { in China and } \\
\text { employed in } \\
\text { diverse } \\
\text { developing } \\
\text { countries } \\
\text { like India, } \\
\text { Nepal, } \\
\text { Uganda and } \\
\text { Tanzania }\end{array}$ \\
\hline $\begin{array}{l}\text { Balloon/Bagdigester } \\
\text { Inlet pipe }\end{array}$ & $\begin{array}{l}\text { This unit comprises a plastic bag connected } \\
\text { with an inlet in order to introduce the } \\
\text { feedstock. The slurry is extracted by the } \\
\text { outlet. The bio gas is released through the } \\
\text { outlet pipe on top of the bag }\end{array}$ & $\begin{array}{l}\text { Developed } \\
\text { in Latin } \\
\text { American } \\
\text { countries } \\
\text { and } \\
\text { employed in } \\
\text { Africa and } \\
\text { South Asian } \\
\text { Countries }\end{array}$ \\
\hline
\end{tabular}

\subsection{Limitations of Prevailing Technologies}

According to the survey, there are about 369 biogas systems are available in Sri Lanka. Further, the survey reveals that nearly $30 \%$ of the biogas systems are functional and $70 \%$ of the household biogas systems are not in mobilization. This is happened due to the lack of knowledge, lack of credit facility, lack of extension work, high initial cost and low output, the usage of this biogas unit is declined. Therefore, developing a domestic biogas unit for cooking with very simple technology is highly motivated.

\subsection{Factors Effecting Bio Gas Production}

While designing small scale Anaerobic digester for domestic environment for treatment of organic waste, it is highly recommended to consider the factors like characteristics of waste, environmental, social, technical and economic conditions. Since the temperature, $\mathrm{Ph}$ value, retention time and composition of food waste are some of the most important factors they are described clearly with their operating conditions.

\subsubsection{Temperature}

Operating temperature is highly considerable feature when deciding the performance of the anaerobic digesters because it is an essential element for the existence of microorganisms. In addition to this the bacteria have two optimal temperature ranges, called mesophilic and thermophilic. The operating temperatures of mesophilic and thermophilic digesters are $25-40{ }^{\circ} \mathrm{C}$ and $50-65^{\circ} \mathrm{C}$ respectively. Thermophilic digesters permit higher rate of loading and produce higher amount methane. Due to the higher temperature, the retention time is less because of the reaction of degradation is very fast. Nevertheless, the thermophilic bacteria are highly sensitive to 
contaminants and environmental changes. Due to the additional energy requirement for self-heating, it is not that much suitable for commercial requirements [1,9,19-23].

\subsection{2 $\mathrm{pH}$ Value}

Though the micro -organisms need alkaline environment the recommended $\mathrm{pH}$ value is 7.0-8.0. The ratio of acidity and alkalinity and the carbon dioxide content decides the $\mathrm{pH}$ inside biogas digester. The concentration of volatile acid measured by acetic acid should be below $2000 \mathrm{ppm}$ for the normal fermentation [25]. However, higher the concentration significantly inhibits the methanogenic action of micro-organisms [9,19-21].

\subsubsection{Retention Time}

The retention time in the anaerobic digesters is determined by the average time needed for decomposition of the organic material, measured by the chemical oxygen demand (COD) and the biological oxygen demand (BOD) of the influent and the effluent material [23]. In this sense, the substrate should be kept for a longer to reach the appropriate conditions of reaction [24]. However, the reaction rate declines with longer retention time. Basically, the required time depends on the type of feeding, environmental conditions and the use of the digested material [23]. However, the optimal retention time for complete biological conversion is, 12-24 days for thermophilic and 15-30 days mesophilic digester [19-26].

\subsubsection{Composition of Food Waste}

The exact requirement of the composition of food waste is a vital during the design of biogas unit to reach the efficient biomethanization. Because the biomethanization depends upon four main components like proteins, lipids, carbohydrates, and cellulose [24]. The maximum methane yields accompanying reactor having surplus of lipids but necessitates higher retention time. Further, the methanization is fast in the system containing excess of protein followed by cellulose and carbohydrates [24]. The component composition assessment of food waste from different origin with respect to the percentage of dry weight, the house-hold waste contains $60.7 \%$ carbohydrates, $14.4 \%$ proteins and $14.04 \%$ lipids [19-26].

\section{Materials and Methods}

\subsection{Design of Model}

Since this anaerobic bio gas unit is to be used for cooking in domestic level it is vital to design the parameters in an effective and efficient manner. As an initial step, the digester volume, height and width are designed by considering the maximum daily charge. Then the gas storage unit is designed by considering all essential factors. After that the inlet tube to digester is also designed. According to the conceptual designs, the optimal design parameters are proposed. Table 3 given below illustrates the design parameters and Figure 3 shows the proposed model of this biogas unit. In order to fabricate this unit in a cost-effective manner, the 55 gallons capacity of blue tight head High Density Poly Ethylene (HDPE) plastic drum with the wall thickness of $2.2 \mathrm{~mm}$ is chosen for the digester. On the other hand, the cylindrical gas storage unit is fabricated by using $1.5 \mathrm{~mm}$ thickness of sheet metal. The $35 \mathrm{~mm}$ diameter hollow steel pipe with the fins at the bottom end is attached to the gas storage 
unit to move up and down along the central shaft. Here, the fins are allowing to use the gas storage unit as a stirrer for the digester.

\section{Table 3}

Design parameters of the Biogas unit

\begin{tabular}{ll}
\hline Design parameters & Value \\
\hline Daily production of bio gas $\mathrm{V}_{\mathrm{o}} /\left(\mathrm{m}^{3} /\right.$ day $)$ & $8.746 \times 10^{-3}$ \\
Retention time $/($ days $)$ & 15 \\
Digester Volume $\mathrm{V}_{\mathrm{d}} /\left(\mathrm{m}^{3}\right)$ & 0.1312 \\
Diameter of the digester tank $/(\mathrm{m})$ & 0.5 \\
Height of the digester tank $/(\mathrm{m})$ & 0.668 \\
Volume of the gas holder $\mathrm{V}_{\mathrm{g}} /\left(\mathrm{m}^{3}\right)$ & 0.765 \\
Hydrostatic pressure on the walls of the digester $\mathrm{Ph} /\left(\mathrm{Kg} / \mathrm{m}^{2}\right)$ & 229.8 \\
Biogas inlet tube diameter $/(\mathrm{mm})$ & 110 \\
\hline
\end{tabular}

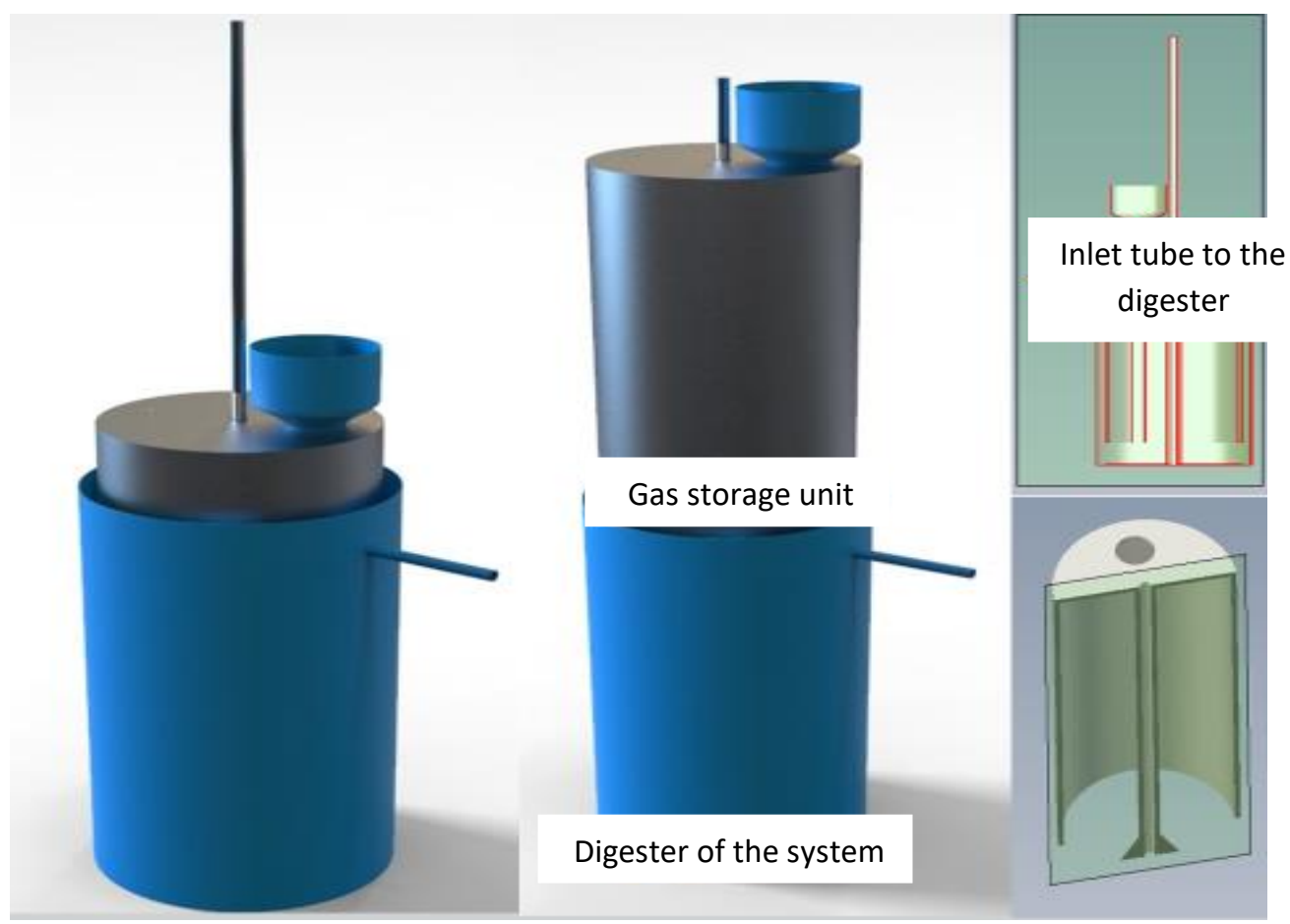

Fig. 3. Proposed model of the biogas unit

\subsection{Implementation of the Model}

As per the design parameters described, initially each and every sub component were implemented. Then these subcomponents were assembled to reach the entire system as illustrated in Figure 4. 


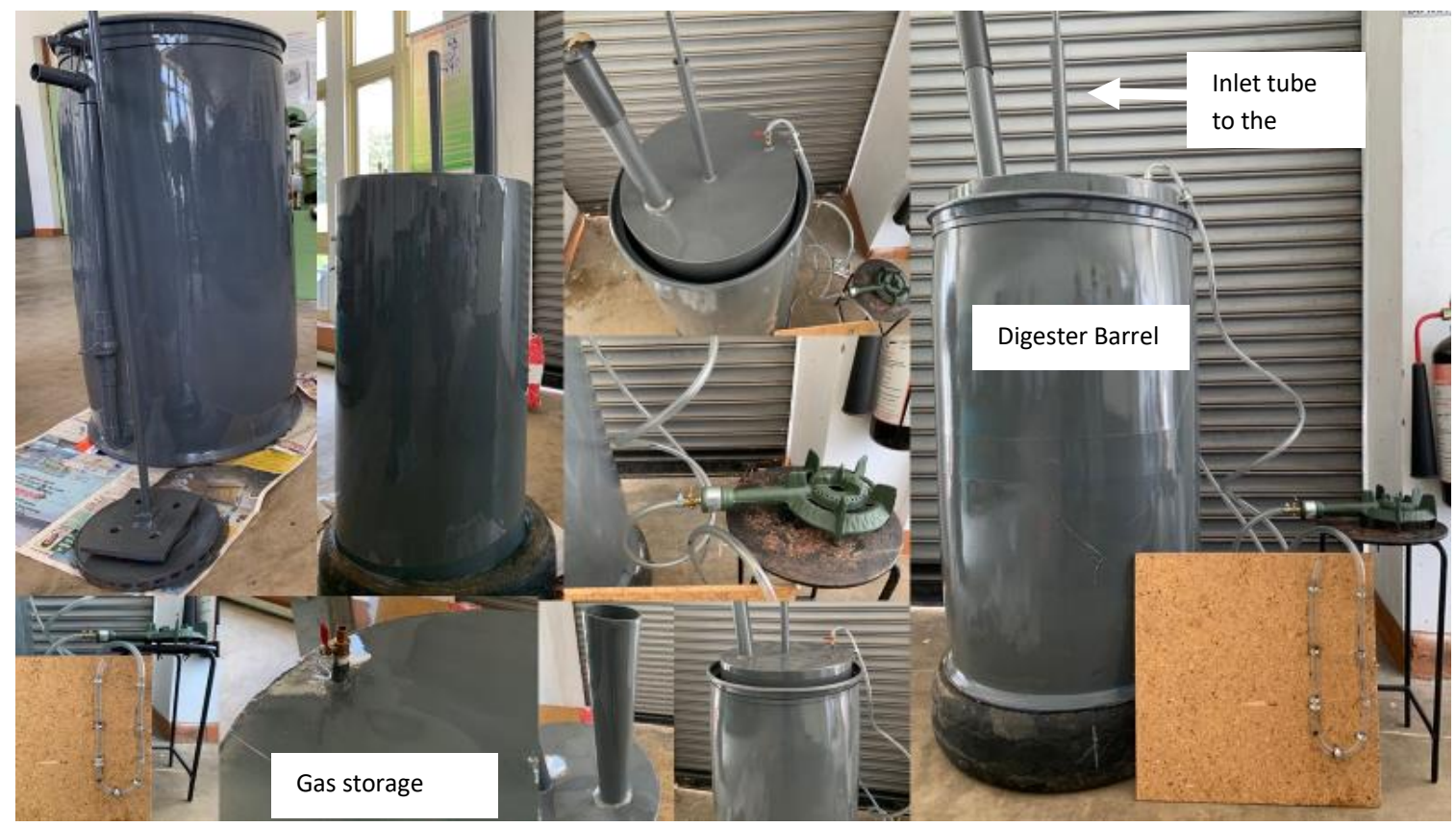

Fig. 4. Implemented biogas system

\section{Results and Discussion}

In order to test and validate this fabricated unit initially water with $\mathrm{pH} 6.0$ was added until $3 / 4$ of the digester. Then $2 \mathrm{Kg}$ of organic waste including cow dung and kitchen waste was mixed with 10 liters of water once in every two days, for two weeks. The Ph value of the effluent was tested frequently. When the $\mathrm{pH}$ value reached around 6.8-7.5, then the mix will start to produce biogas. After that food waste was added slowly every day. Then there are about 50 liters of biogas per day was collected. As per the interview with domestic users, this amount of biogas would be very much useful to save around 200 Sri Lankan rupees per day from other energy sources. On the other hand, the energy calculation reveals that, $1 \mathrm{~m}^{3}$ of bio gas contains $1.83 \mathrm{KWh}$.

As per the test results and energy calculation, it is highly essential to improve the quality of the methane gas. Further research studies have to be carried out on microbiological actions on four processes of bio gas production and to analyze the feasibility of two stage bio gas production and its efficiency. Statistical research studies are highly recommended to analyze the BOD values of Sri Lankan waste content. In addition to this, it is necessary to regulate design standards for pits to be used in various waste categories like poultry, domestic and industrial wastes. Further, necessary steps have to be taken to analyze the feasibility for the construction and distribution of large-scale biogas plants.

\section{Conclusion and Future Directions}

Though the bio gas generation by biodegradable waste is a very old technique this would be a major energy source all around the world. But in the Sri Lankan context anaerobic digestion of kitchen waste in small scale digester tanks is feasible alternative to the other means of bio gas generation. Hence the proposed model is highly recommended due to the special characteristics like lower operating cost as well as fabrication cost and user-friendly etc. In addition to this organic fertilizer will also be produced as byproduct. Further, future improvements are highly essential to develop special stoves for methane and filling in a container in a safe way to promote in Sri Lankan domestic market. 


\section{References}

[1] Deheragoda, C. K. M. "Renewable energy development in Sri Lanka." Tech Monitor 26, no. 6 (2009): 49-55.

[2] Muvhiiwa, Ralph, Diane Hildebrandt, Ngonidzashe Chimwani, Lwazi Ngubevana, and Tonderayi Matambo. "The impact and challenges of sustainable biogas implementation: moving towards a bio-based economy." Energy, Sustainability and Society 7, no. 1 (2017): 1-11. https://doi.org/10.1186/s13705-017-0122-3

[3] Prasad, Ravita D. "Empirical Study on Factors Affecting Biogas Production." ISRN Renewable Energy 2012. https://doi.org/10.5402/2012/136959

[4] Arthur, Richard, Martina Francisca Baidoo, and Edward Antwi. "Biogas as a potential renewable energy source: A Ghanaian case study." Renewable Energy 36, no. 5 (2011): 1510-1516. https://doi.org/10.1016/i.renene.2010.11.012

[5] Obileke, KeChrist, Helen Onyeaka, Osaze Omoregbe, Golden Makaka, Nwabunwanne Nwokolo, and Patrick Mukumba. "Bioenergy from bio-waste: a bibliometric analysis of the trend in scientific research from 1998-2018." Biomass Conversion and Biorefinery (2020): 1-16. https://doi.org/10.1007/s13399-020-00832-9

[6] Aworanti, Oluwafunmilayo Abiola, Samuel Enahoro Agarry, and Oladipupo O. Ogunleye. "Bioenergy recovery from the anaerobic digestion of mixed animal wastes co-digested with mixed fruit wastes." Umudike Journal of Engineering and Technology 4, no. 1 (2018): 135-148.

[7] Nallamilli, Srinvasa Reddy, Sathiraju V. Satyanarayana, and G. Sudha. "Bio Gas Generation from Biodegradable Kitchen Waste." International Journal of Environment, Agriculture and Biotechnology 2, no. 2 (2017): 689-694. https://doi.org/10.22161/ijeab/2.2.15

[8] Sudha, G., S. V. Satyanarayana, Srinivasa Reddy, K. Kamala. "Biodegradable Kitchen Waste a Sustainable Energy Resource for the Biogas Generation-A Case Study." International Journal of Research and Analytical Reviews 5, no. 4 (2018): 770-774.

[9] Dilhani, J. A. T., S. W. Alahakoon, A. De Alwis, M. Jayaweera. "Biogas Production Using Fruit Wastes." National Energy Symposium 2014 (2014): 71-81.

[10] Visvanathan, C., and J. Trankler. "Municipal Solid Waste Management in Asia: A Comparative Analysis." In Workshop on Sustainable Landfill Management, pp. 3-15. 2003.

[11] Glawe, Ulrich, Chettiyappan Visvanathan, and Mohammed Alamgir. "Solid waste management in least developed Asian countries-a comparative analysis." In International Conference on Integrated Solid Waste Management in Southeast Asian Cities, pp. 5-7. 2005.

[12] Al-Wahaibi, Abeer, Ahmed I. Osman, H. Ala'a, Othman Alqaisi, Mahad Baawain, Samer Fawzy, and David W. Rooney. "Techno-economic evaluation of biogas production from food waste via anaerobic digestion." Scientific Reports 10, no. 1 (2020): 1-16. https://doi.org/10.1038/s41598-020-72897-5

[13] Raji, Wuraola A., Yakubu Yerima, and P. T. Alufar. "Comparative Study on the Rates of Production of Biogas from Organic Substrates." Energy and Power Engineering 10, no. $12 \quad$ (2018): 508-517. https://doi.org/10.4236/epe.2018.1012032

[14] IRENA. Biogas for domestic cooking: Technology brief. International Renewable Energy Agency, Abu Dhabi, 2017.

[15] Liu, Ting, Xiaoqin Zhou, Zifu Li, Xuemei Wang, and Jiachen Sun. "Effects of liquid digestate pretreatment on biogas production for anaerobic digestion of wheat straw." Bioresource Technology 280 (2019): 345-351. https://doi.org/10.1016/i.biortech.2019.01.147

[16] Shafie, Shafini Mohd, Zakirah Othman, Norsiah Hami, Salmah Omar, and A. Harits Nu'man. "Solid Oxide Fuel Cells Fueled with Biogas in Malaysia: A Review of Potential." Journal of Advanced Research in Fluid Mechanics and Thermal Sciences 81, no. 1 (2021): 18-25. https://doi.org/10.37934/arfmts.81.1.1825

[17] IRENA. Biogas for domestic cooking: Technology brief. International Renewable Energy Agency, Abu Dhabi, $2016 \mathrm{~b}$.

[18] Bhol, Jyotiprakash, B. B. Sahoo, and C. K. Mishra. "Biogas digesters in India: A review." In National Conference on Renewable and New Energy Systems. Odisha: SIET. p1-6. 2011.

[19] Srivastava, Sunil Kumar. "Advancement in biogas production from the solid waste by optimizing the anaerobic digestion." Waste Disposal \& Sustainable Energy 2, no. 2 (2020): 85-103. https://doi.org/10.1007/s42768-02000036-x

[20] Peiris, Ambagaha Pathirage Thanushka Sandaruwan. "Feasibility study of production of bio methane from bio wastes in Sri Lanka and develop cost model for the production process." Master thesis, University of Gavle (2016).

[21] Pilloni, Martina, and Tareq Abu Hamed. "Small-Size Biogas Technology Applications for Rural Areas in the Context of Developing Countries." Anaerobic Digestion in Natural and Built Environments (2021).

[22] Vlatka Petravić-Tominac, Nastav Nikola, Buljubašić Mateja, and Šantek Božidar. "Current state of biogas production in Croatia." Energy, Sustainability and Society 10, no. 1 (2020). https://doi.org/10.1186/s13705-020-0243-y 
[23] Mir, Muzaffar Ahmad, Athar Hussain, and Chanchal Verma. "Design considerations and operational performance of anaerobic digester: A review." Cogent Engineering 3, no. 1 (2016): 1181696. https://doi.org/10.1080/23311916.2016.1181696

[24] Ray, N. H. S., M. K. Mohanty, and R. C. Mohanty. "Anaerobic digestion of kitchen wastes: "biogas production and pretreatment of wastes, a review"." International Journal of Scientific and Research Publications 3, no. 11 (2013): 286-291. 